\title{
Photovoltaic Luminaire of Low Cost For Public Streets
}

\author{
Spacek, A. D. ${ }^{1}$, Neto, J. M. ${ }^{1}$, Clemente, L. G. ${ }^{1}$, Ando Junior, O. H. ${ }^{2}$, Malfatti F. C. ${ }^{3}$ \\ ${ }^{1}$ Department of Industrial Automation \\ SATC, Beneficent Association of Santa Catarina Coal Industry \\ Street Pascoal Meller, 73. Criciúma-Sc (Brazil) \\ Phone/Fax number: +5548 34317568, e-mail:anderson.spacek@satc.edu.br; joao.neto@ satc.edu.br \\ ${ }^{2}$ Department of Renewable Energies Engineering \\ UNILA, Federal University of Latin American Integration \\ Av. Sílvio Américo Sasdelli, 1842. Foz do Iguaçu, PR (Brazil) \\ Phone/Fax number: +55 45 35292832, e-mail: oswaldo.junior@unila.edu.br \\ ${ }^{3}$ School of Engineering \\ UFRGS, Federal University of Rio Grande do Sul \\ Av. Osvaldo Aranha, 103. Porto Alegre-Rs (Brazil) \\ Phone/Fax number: +55 51 3308-31.29, e-mail: malfatti@ufrgs.br
}

\begin{abstract}
Public lighting is essential to quality of life in cities is directly related public security valuing urban areas such as parks, monuments, buildings, recreational areas and highways. However, street lighting can provide high levels of waste of electrical energy due to inefficient use of equipment. This work presents an alternative to the current public illumination system. The proposal consists of an Integrated System for Lighting based on High Brightness LEDs with Power by photovoltaic panels, presents a brief study on the components that make up the whole system development steps and the results obtained.
\end{abstract}

\section{Key words}

Environment; Alternative Sources; Public Illumination; LED.

\section{Introduction}

With the energetic crisis of 2011 in Brazil, it was evident the necessity of implementation of the National Program of Efficient Public Illumination - Reluz aiming to reduce the electric energy consumption in the public illumination system in Brazilian cities. The initial proposal of the program Reluz is the substitution of old lamps for lamps of sodium steam because they present higher efficiency [1].

Seeing that there are approximately 15 million public illumination points installed in Brazil, they represent an electric energy consumption of public illumination of about $3 \%(9,7$ billion of $\mathrm{kWh} /$ year $)$ of the consumed energy in the country or approximately $4,5 \%(2,2 \mathrm{GW})$ of the national demand [2].

Most energy distributors use public luminaries equipped with discharge lamps combined with reactors, because it is a diffused technology nowadays and also to cater to the requirements of the Brazilian regulatory norm for public illumination NBR 5101/2012 [3].

The public illumination job costing is seen in the Federal Constitution in the 149-A article that determines that the cities and the Distrito Federal must institute contribution for the job costing of the public illumination services [4-6].

Therefore, the current paper presents the development of a self-sustaining luminary using LED's power for application in public streets, so that it attends the minimum conditions demanded by the regulatory norms in effect. The prototype is characterized as an off-grid system.

\section{Proposed Systems}

The prototype aims to attend technical lighting criterions, such as, minimum index of illumination and color reproduction, uniformity factor and to avoid glare of the public streets users. In that way, the research was made based on the block diagram from Fig. 1.

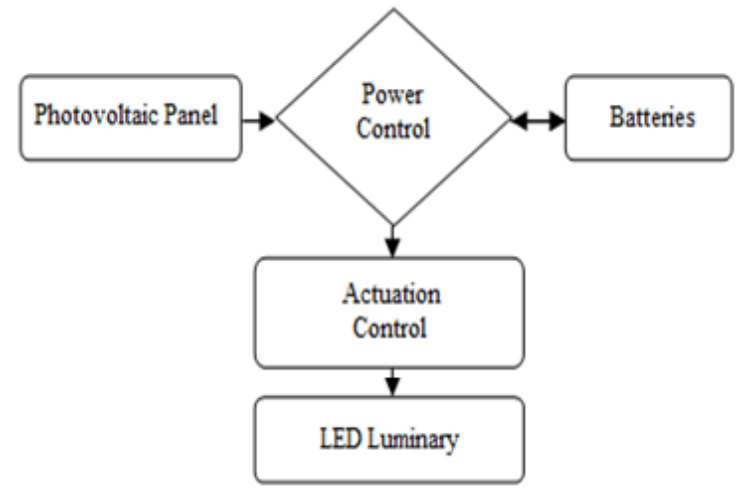

Fig.1: Operation Flowchart 
It was opted the utilization of an off-grid photovoltaic generation system, considering that the solar irradiation incidence levels in the Brazilian territory are expressive, its variation is around 14 and $22 \mathrm{MJ} / \mathrm{m}^{2}$ with average duration of about five hours a day [5-7]. For the generation system dimensioning, it was disregarded daily changes of electric energy consumption.

The electric energy potential generated by the photovoltaic system is stored in Nickel-metal hydride (NiMH) battery bank, and they are being applied in big scale applied in electric vehicles. They have high index of energy storing capacity, do not present memory effect because they are exempted of cadmium and lead, and their environmental impacts are reduced for not having these heavy metals in their constitution [8].

Thus, the battery bank is composed by 36 battery of type AA, with capacity of $3600 \mathrm{mAh}$ and $1,2 \mathrm{~V}$ each one. They were grouped in six parallel connected sets, each set has six battery in series, which represents the capacity of 21.6 Ah and 7.2 V. For dimensioning, the base is the discharge about Battery discharge and rechargeable from the company STA at rate of $1 \mathrm{C}$, that is, at the same discharge current of the battery nominal capacity [9].

The battery bank definition considered that the luminary is actuated during 10 hours a day. And the luminaries are charged through the photovoltaic system actuated above the luminary skin in an anatomic form (see Fig. 2).
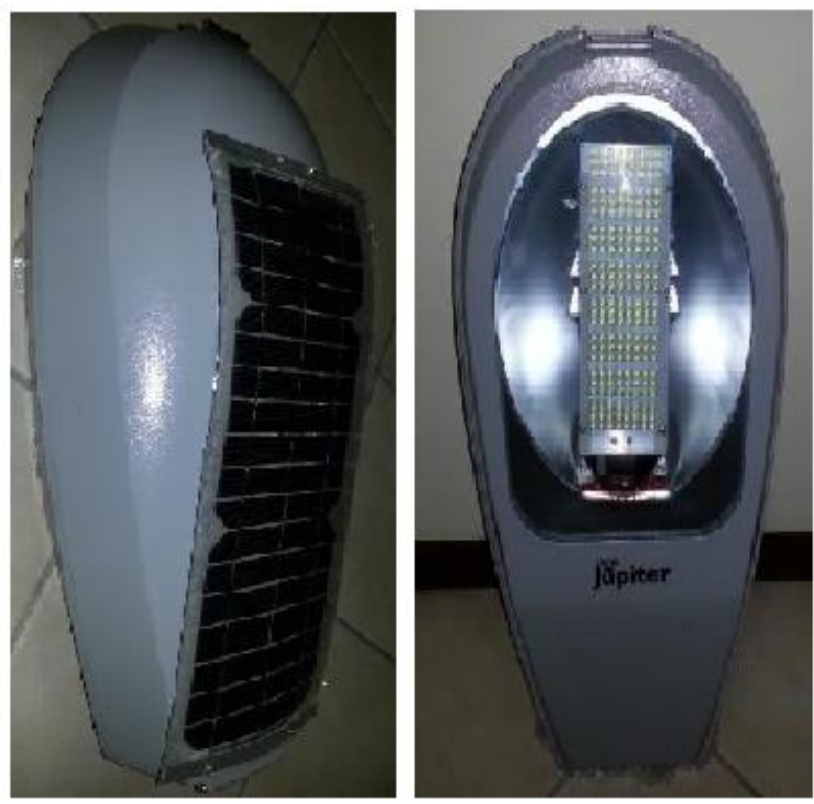

Fig 2: Parts of Luminaire

\section{A. illumination control}

The control circuit is responsible for turn on luminaire, this electronic circuit is equipped with a LDR to detect the luminosity of the external environment. In accordance with the NBR 5123: 1998 establishing the drive photocells with illuminance level around 15 lux and the turn off around 25 lux. So that, at sundown the LDR identify absence of natural light and light the luminaire.

The drive control consists of two independent light sensor circuits. Characteristic adopted in order to divide the drive control, so that the luminaire operates in two stages, with $50 \%$ and $100 \%$ of its brightness. The turn on of the LEDs $50 \%$ occurs at the moment the luminosity of the external environment has climbed 15 lux, and the remaining $50 \%$ as soon as the external light decay to 13 lux. Thus increase the autonomy of the luminaire, without compromising its security on the street

\section{B Development Costs}

The prototype has characteristics which differ from technologies applied today in public luminaries. In particular, use of LED technology as the light source and the fact that it is self-sustaining, as it uses a photovoltaic panel of semi flexible monocrystalline silicon as source of electricity, which will be stored in a battery bank consists of rechargeable batteries of nickel metal hydride type AA. Thus eliminates the connection with the power grid which characterizes the system as off-grid. These characteristics directly influence the economic viability analysis, since the components used are imported.

Since this is a prototype were purchased few components, which resulted in high individual cost of used items. The components used in assembling of the luminaire were basically acquired in international sites, except mechanic structure the luminarie and electronic components.

The total amount invested in the prototype was $\mathrm{R} \$$ 580.55. However, it will proportion the luminaire to be produced on a large scale costs will be reduced, as in buying large quantities of the individual components values are reduced and there a possibility of negotiation about the costs with suppliers. In order to make the economic viability with more attractive.

\section{Analysis and Discussion of Results}

With the aim of validating the prototype, measurements were made of illuminance to verify its adaptation to the NBR 5101:2012. In that norm, the streets are classified in five classes, and the minimum illuminance levels change between 5 and 30 Lux, according to the type of streets, pedestrians and vehicles flow.

In order to facilitate the follow-up of the results and to compare with the sodium lamp, the luminaire was installed in the parking lot 1 of Faculdade SATC. This characterized by flow of vehicles and pedestrians is mild.

It was used the method of peer-to-peer measurement described in the norm, to perform the illuminance measures and calculations. It stipulates that the distance between the measurement points is the maximum of 1.5 meters, for distance between luminaries until 50 meters. With the usage of the luxímetro, there were made measurements of each point, and it was elaborated the tables 1 and 2 that present the performances of the luminary and the sodium-vapor lamp, respectively.

Table 1: Prototype Luminary Measures

\begin{tabular}{|c|c|c|c|c|c|c|c|c|c|}
\hline Point & P1 & P2 & P3 & P4 & P5 & P6 & P7 & P8 & P9 \\
\hline $\begin{array}{c}\text { Measure } \\
\text { (lux) }\end{array}$ & 23 & 22 & 22 & 22 & 23 & 19 & 21 & 21 & 19 \\
\hline
\end{tabular}


Table 2: Measurements of $250 \mathrm{~W}$ sodium-vapor luminary

\begin{tabular}{|c|c|c|c|c|c|c|c|c|c|}
\hline Point & P1 & P2 & P3 & P4 & P5 & P6 & P7 & P8 & P9 \\
\hline $\begin{array}{c}\text { Measure } \\
\text { (lux) }\end{array}$ & 43 & 59 & 65 & 49 & 62 & 69 & 46 & 61 & 75 \\
\hline
\end{tabular}

With the luxímetro, measurements of each point were made, and later it was calculated the mean according to the equation (1).

$$
E_{\text {mean }}=\left(\frac{P 1+P 3+p 7+P 9}{16}+\frac{P 2+P 4+P 6+P 8}{8}+\frac{P 5}{4}\right)
$$

In Fig. 3, the location of the luminaire is presented in tests illuminance structure mounted to the measuring mesh tests through Point-to-point method, with distance between points of 1.5 meters.

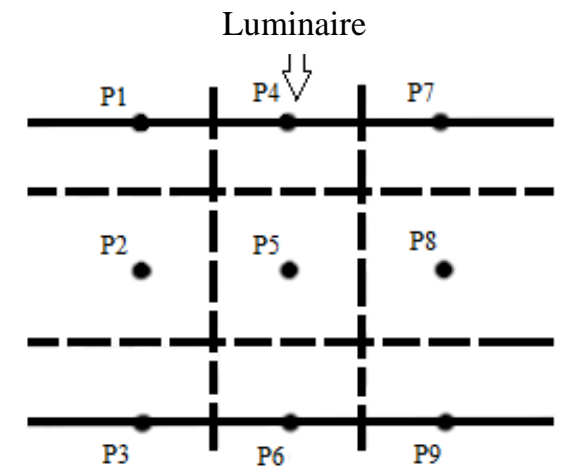

Fig. 3: Test Measurement Mesh

By means of calculation, it has come to the value of the illumance mean (Emean $)$ that is 21.56 Lux. Meanwhile, the luminary aside, equipped with the $250 \mathrm{~W}$ sodiumvapor lamp, presented a value of illumance mean of 59.43 Lux. Thus, this procedure validates the usage of LFIP, for streets of class V2 with medium traffic volume.

\section{Economic Analysis}

Based on the costs of the components used for the development of prototype and returns with the implementation of the luminaire it was used tools of economic engineering, such as; the attractiveness hurdle rate (AHR), the return on investment time (discounted Payback)the liquid present value (LPV), internal rate of return (IRR) and the equivalent uniform annual value (EUAV). In order to evaluate the attractiveness of the investment for electric power concessionaires, viability analyzes it was used two situation.

The first case evaluates the economic viability of using prototype (LFIP) in substitution the luminaire with lamp of sodium steam $250 \mathrm{~W}$. The second case assess the economic viability of using LFIP replacing the luminaire with lamp of sodium steam $150 \mathrm{~W}$, due to be largely used in street lighting. Since, to do the calculations were observed consumption data of lamps and reactors, the cost of $\mathrm{kWh}$, and prototype costs, and disregarding the costs reflectors and structures, with the aim of this work to incorporate the technology studied and reflectors lamppost used nowadays.
The analysis of the economic viability of the first case is realized through of comparative of the prototype with lamp of sodium steam $250 \mathrm{~W}$, since the field tests were conducted in the same place. Was considered useful life of the lamp and reactor in 8 years, cost $\mathrm{R} \$ 99.09$. Was considered its activation daily with an average duration of around $10 \mathrm{~h}$ because of testing period be comprehended in the summer period. The price paid by $\mathrm{kW} / \mathrm{h}$ is $\mathrm{R} \$ 0.36$ and as the luminaire features $250 \mathrm{~W}$ of power, the annual cost of electricity is approximately R \$ 324.00.

The investment cost for the development of photovoltaic lamp (LFIP) was $\mathrm{R} \$ 580.55$. Was considered useful life of the prototype in 20 years in virtue of kit consist of electronic components, and LED's , is estimated life around 80,000 hours and the attractiveness hurdle rate (AHR) of $16.81 \%$ per year, having as based on the SELIC added $6 \%$.

Through calculation, was determined values of LPV which signifies the bring the money invested for the today and resulted in positive balance of $R$ \$ 2,661.613 which is 3 times the invested initial value; EUAV, the equivalent annual value, results R \$ 468.27 annually yield; and IRR of $43.82 \%$, in order to eliminating the need of the attractiveness hurdle rate be larger than the internal rate of return because the investment will have profit of $\mathrm{R} \$$ 468.27 per year over the life of the LFIP. Thus it can be said that the project is economically viable. Through the payback method discounted, it was found which feedback of investment occurs in a period less than three years, which results in the viability of the prototype.

The analysis of the economic viability of the case 2 has the same characteristics analysis done for the case 1, however the study is conducted through of comparative of the of the prototype with lamp with lamp sodium steam $150 \mathrm{~W}$. life was considered useful lamp and reactor kit of eight years, and cost $\mathrm{R} \$ 81.43$, daily activation with an average duration of around $10 \mathrm{~h}$, the price paid by $\mathrm{kWh}$ is $\mathrm{R} \$ 0.36$, and as the luminaire has power of $150 \mathrm{~W}$, the annual cost of electricity is approximately R \$ 194.40.

Through calculation, was determined values of LPV and resulted in positive balance of $\mathrm{R} \$ 1$ 1,234.96; EUAV results R\$ 217.31 annually yield; and IRR of $19.30 \%$, because the attractiveness hurdle rate is larger than the internal rate of return, thus it can be said that the project is economically viable because it will create an annual profits during the useful life of the equipment. Once the investment takes approximately four years to pay the investment.

\section{Indirect Benefits}

The new technological design proposed in this paper shows in addition of the gains on reduction in electricity consumption and longer life when compared to other technologies, also replicates in indirect benefits. To be self-sustainable, provides load removal on power grid because, nowadays consumption with street lighting in Brazil is 9.7 billion $\mathrm{kWh} /$ year, about $3 \%$ of the electricity consumed in the country. Mainly in the period power concessionaires consider as peak time, with 3 consecutive hours daily between $6 \mathrm{pm}$ and $9 \mathrm{pm}$, in which the demand of electricity consumption is highest. In proportion as, there are many loads connected in this interval, such as 
industry, street lighting and the fact that people are arriving into their houses.

Since in LEDs are used as light source, there is no emission of ultraviolet and infrared radiation to provide a healthy environment for people. LED's have high color rendering index, $80 \%$ while the lamp of sodium steam has IRC $22 \%$, which provides a pleasant and efficient lighting, and facilitates the perception and visualization of objects, pedestrian lanes, and signaling on the streets.

The technology used in LFIP can be incorporated into others luminaire models, because its components are modular and can take many constructive forms. Can to provide easy access for maintenance, the luminaire components are coupled to the system via terminal connector quick coupler. Allowing any maintenance technicians accomplish repairs becoming the agile service, compared to the eventual replacement of reactors, photocells and sockets in luminaires with discharge lamps. Although, the developed luminaire has long service life, consist of electronic equipment requires minor interventions to perform maintenance, and above all are reduced fuel costs for travel, equipment costs and costs of working hours of maintenance professionals.

\section{Conclusion}

The main objective of this paper is to show the capability of the prototype generated by lighting luminaire that meets the norms established by the government and presented as an affordable alternative to be implemented on streets.

The prototype was presented as a viable solution to be applied in public lighting presents several benefits such as improvements in lighting quality, reduce energy consumption, use of alternative resources in order to reduce demand during peak hours.

The consumption of electricity in Brazil is about $4.5 \%$, or $2.2 \mathrm{GW}$ of domestic demand, it is estimated that in substitution the technology used today in public lighting, the use of LFIP can provide considerable relief consumption in the national grid . Especially in the critical period of peak hours, there is high peak consumption. It is estimated that, with the use large-scale LFIP, we would have a reduction in energy consumption around 808 million $\mathrm{kWh}$ monthly, enough to supply the monthly consumption demand of a city with $12,742,278$ people.

Besides reflecting the energy saving, the use of photovoltaic luminaire designed for public lighting, presents several indirect benefits passers and car drivers as it provides the most pleasant and efficient lighting, in order to facilitate the perception and visualization of objects, pedestrian lanes, and signage. Also has benefits in reducing interventions for maintenance, environmental issues and application versatility.

Based on the analysis of results obtained through the field test conducted on the campus of SATC, it is observed that in case 1, compared to a sodium vapor lamp $250 \mathrm{~W}$, that the prototype meets the requirements established by standard for application in the process included in the V2 class, such as minimum average illuminance and has better color rendering index and visual comfort. In addition to removing the burden of a lamp with $250 \mathrm{~W}$ of power grid, which is the economy of
$75 \mathrm{kWh}$ per month. Also in case 2, compared to a luminaire equipped with discharge lamp sodium vapor $150 \mathrm{~W}$, the prototype meets the requirements of the standard for the way V2 class and provides savings of 45 $\mathrm{kWh}$ per month.

However, to gain is better conclusions about the behavior of LFIP, the test period should be extended in order to cover the four seasons. In order to monitor the operation of the prototype with different climatic conditions typical of each season. Since, in the south of Brazil the incidence rates of solar radiation varies with the seasons. As for the cost of the light, it is observed that for the two cases analyzed the investment is economically viable, because through the payback method discounted, the investment pays for itself in a period of less than three years for 1 and Case 2 a period of five years.

\section{References}

[1] NASCIMENTO,Alan. Análise do uso da tecnologia LED na iluminação pública: Estudo das perspectivas de aplicação na cidade de São Paulo. 2012. 19 - 23 f. Dissertação Curso de Pós-Gradução em Energia, Universidade Federal do ABC, Santo André 2012.

[2] ELETROBRAS. Programa Nacional de Conservação de Energia Elétrica - PROCEL; Iluminação Pública. Disponívelem: $<$ http://www.eletrobras.com/elb/main.asp?Tea $\mathrm{mID}=\%$ 7BEB94AEA0-B206-43DE-8FBE-

6D70F3C44E57\%7D >. Acesso em: 1 ago. 2014.

[3] NBR 5101: Iluminação Pública. Associação Brasileira de Normas Técnicas. Rio de Janeiro: 2012. 35p.

[4] SANTANA, Rosa Maria Bomfim. Iluminação pública: Uma abordagem gerencial. 2010. 14 - 44 f. Dissertação Curso de Regulamentação da Indústria de Energia, Universidade Salvador, Salvador 2010.

[5] NASCIMENTO,Alan. Análise do uso da tecnologia LED na iluminação pública: Estudo das perspectivas de aplicação na cidade de São Paulo. 2012. 206 f. Dissertação (Mestrado em Energia). Universidade Federal do ABC, Santo André 2012.

[6] ALIL, Mokhtar; ORABIL, Mohamed; ABDELKARIML, Emad; QAHOUG, Jaber A.Abu; AROUDI, Abdelali El. Design and Developmente of Energy: Streer LED Light System. IEEE Transactions on Industry Applications. p. 1-7, dez. 2011.

[7] RUTHER, Ricardo. Edifícios Solares Fotovoltaicos: o potencial da geração solar fotovoltaica integrada a edificações urbanas e interligada à rede elétrica pública no Brasil. Florianópolis: LABSOLAR, 2004.

[8] NOCE, Toshizaemomi. Estudo do funcionamento de veículos elétricos e contribuíções ao seu aperfeiçoamento. 2009. 50-63 f. Dissertação (Mestre) Curso de Engenharia Mecânica, Pontifica Universidade Católica de Minas Gerais, Belo Horizonte, 2009.

[9] STA - Sitemas e Tecnologia Aplicada. Descarga de baterias. http://www.staeletronica.com.br/artigos/descargade-baterias. Acesso em: 19 set. 2014. 